\title{
Coming to Grips with Caribbean Complexity
}

\author{
Anthony P. Maingot \\ Department of Sociology, Florida International University, \\ Miami FL 33199, U.S.A. \\ maingota@fiu.edu
}

Carrie Gibson, Empire's Crossroads: A History of the Caribbean from Columbus to the Present Day. New York: Atlantic Monthly Press, 2014. xxviii + 447 pp. (Cloth US\$28.00)

Jorge Rodríguez Beruff \& José L. Bolívar Fresneda (eds.), Puerto Rico en la Segunda Guerra Mundial: El Escenario Regional. San Juan: Ediciones Callejón, 2015. 608 pp. (Paper US\$ 29.95)

Maurice St. Pierre, Eric Williams and the Anticolonial Tradition: The Making of a Diasporan Intellectual. Charlottesville: University of Virginia Press, 2015. ix + 254 pp. (Paper US\$27.59)

Reviewing these three books compels one to ask whether there was need for another general history of the Caribbean "from Columbus to the present day," another biography on Eric Williams, and another history of Puerto Rico in World War II. That question can be answered positively only if the three books being reviewed bring new facts and interpretations. That said, these three quite different books prove, each in turn, that Caribbean history, like all history, is a story without an end, a book with many chapters of varied topics and many more waiting in the wings.

Carrie Gibson's general history reflects who she is. As an historian with a $\mathrm{Ph}$.D. from Cambridge, she shows commendable strengths in European history and the history of Spanish Conquest and colonization (Chapters 1-3). Her thesis that the story of the modern Caribbean really began in 1415 with the conquest of Ceuta and the discovery and exploitation of the Canary Islands, Madeira, Cape Verde, and the Azores makes sense. By the time Columbus and his explorers had crossed the Atlantic, they had had a "colonial education" involving slave labor, sugar cultivation, and the Christianization of the native inhabitants of these Atlantic islands, the Guanches. These parts of her book

(C) ANTHONY P. MAINGOT, 2016 | DOI: 10.1163/22134360-09003004

This is an open access article distributed under the terms of the Creative Commons

Attribution-Noncommercial 3.o Unported (CC-BY-NC 3.0) License. 
are written with verve and sustained by strong evidence. Two good maps and a "Timeline of Key Events" (pp. 352-58) contribute further to the historical descriptions.

Less convincing, however, is her writing as a journalist cum contemporary historian which makes up the rest of the book. As a journalist on a one-year leave from the English daily The Guardian, she is an author in a hurry to "know" or rather, to become acquainted with, the whole Caribbean. On what she calls her "sojourn" she visits twenty-five islands and territories which are described briefly in a section listed as "Gazetteer: The Caribbean (and surroundings)." The great variation in depth and detail given to each attests to great haste, and this in turn explains the many generalizations with which she strings distinct topics together.

The major generalization that seems to undergird the whole book is her evident ideological unwillingness to find anything commendable in 500 years of colonial rule, be it Spanish, British, French, Dutch, Danish or, and certainly, American. The story of all the colonizing powers, she says, is one of extremes: brutality and liberations, oppression and freedom. She does not equivocate when she concludes that "Empire in this book does not offer a reassuring narrative ... To be clear: Europeans brought destruction, chaos and disorder ... resistance and rebellion was all around" (p. xix).

Gibson is so single-minded in her chastising posture that she seemed unable to treat dispassionately even the most important elements of that imperial colonial history. Are we to believe that sugar- that basic element of and motivation for imperial production, the monumental and barbarous of transport of millions from Africa, and contributor to the rise of capitalism-can be so trivially dismissed as a "useless byproduct of a breed of grass," a "worthless commodity" which "transformed-deformed" Caribbean history as well as causing "the rise of consumer society" (p. xxiii)?. Only slightly less absurd is her description of the Caribbean tourism industry - so vital and indispensably a part of contemporary economies - as equivalent to a public relations miasma. She is so fundamentally predisposed to writing mostly about the various abhorrent acts of colonialism that she never ventures to ask the counterfactual question: Were there any periods that contrasted with this dismal panorama of imperial evil which would indicate that not everything was awful about it? A case in point is her treatment of U.S. colonialism. She seems unable to find anything positive in U.S. imperial history. This explains why F.D.R.'s Good Neighbor Policy, a fundamental departure from the preceding history, is dismissed in two sentences (p. 252). It also explains why in the whole discussion of the British decolonization process the names of such British anticolonialists such as Arthur Creech-Jones, Michael Foot, and Stafford Cripps and the active members of the Fabian Colonial Bureau are not mentioned. 
The point is that such sweeping negative judgments without any counterintuitive attempts at uncovering alternatives leads one to agree with Niall Ferguson that the difficulty with the achievements of empire is that they are much more likely to be taken for granted than the sins of empire. "The question is not," he argues counterfactually, "whether British imperialism was without blemish. It was not. The question is whether there could have been a less bloody path to modernity."1

A case in point is that in her otherwise commendable haste to welcome the role of Haiti in destroying its slave-based society, she extends her argument to say that the Haitian Revolution was the "beginning of the end" since the "matter was settled" in 1794 (p. 162). Well, of course it was not settled and it is not clear what role the example of Haiti had on a century of emancipation processes. It took the rise of capitalism and much religious preaching by abolitionists in Britain to end slavery in 1834, the liberal revolutions of 1848 in Europe to end slavery in the French Empire, a bloody Civil War to end it in the United States, a determined anticolonial revolution to end it in Cuba in 1886, and a less bloody but equally committed movement to end it in Brazil in 1888 .

It is an established fact that hasty, one-sided conclusions often result from inadequate causal analysis. This is evident in her analysis of the failure of socialism in Jamaica. She describes Michael Manley as being "initially proCastro" (p. 288) when he was in fact initially a moderate social democrat called back from England to defeat the Marxist clique (the so-called "Four Hs") which was attempting to take over the Peoples National Party. He did adopt a leftist program in his second term in the mid-1970s, but to attribute his electoral defeat in 1980 to the subversive actions of the CIA's "promotion of unrest and shipment of arms" to Manley's enemies is over the top. Not surprisingly, given her lack of evidence, her single source for this highly-charged claim is one article in her own newspaper, The Guardian (p. 297). The haste to lay blame in complex cases which call for judgmental caution is evident in her analysis of the long history of Dominican-Haitian cross-border antagonisms. Since the Dominican Republic and Haiti, she says quite erroneously, "share a common African heritage," Dominican emphasis on a Hispanic heritage is pure racism and this explains the antagonism (p. 254).

Since Cuba is given a whole chapter of 41 pages, it is altogether strange that her analysis of the political history of that country barely touches on the Constitution of 1940 and the party system and labor movements developed

1 Niall Ferguson, 2002, Empire: The Rise and Demise of the British World Order and the Lesson for Global Power (New York: Basic Books), p. xxiv. 
by the Auténticos Grau San Martín and Carlos Prío Socarras. Modern Cuban history cannot be reduced to the study of American imperialism, the actions of Fulgencio Batista, and the rise of Fidel Castro.

In her conclusion, she contradicts the V.S. Naipaul of 1962 who pontificated that "nothing was created in the West Indies" by saying that the region is in fact of central importance. "Whichever way the axis of power tilts," she says enigmatically, "the Caribbean remains in the middle of it all, a crossroads connecting the world" (p. 352). One way she could have illustrated this conclusion of a Caribbean in the middle of it all, was to have done what she did not do: study what is properly called the "Battle of the Caribbean" in World War II. This, after all, was the watershed period which opened the doors to the postWWII decolonization process. As Rafael Cox Alomar correctly claims in the Jorge Rodríguez Beruff and José L. Bolivar Fresneda volume reviewed here, this war led to the "transformación definitiva de la relación colonial" in Puerto Rico and the nonindependent Caribbean (p. 39).

World War II and "The Battle of the Caribbean," ${ }^{2}$ especially the role of Puerto Rico in the final regaining of control of the waters of the Caribbean, is the theme of the well put-together book by Jorge Rodríguez Beruff and José Bolívar Fresneda. ${ }^{3}$ It is composed of an introduction and four sections: "The Caribbean" (six chapters), "War and Society" (four chapters), "The Military" (four chapters), and "Culture" (four chapters). Aside from the key chapters on the military aspects of this period, there are chapters on, to mention a few, the Falange in Cuba and Puerto Rico, the economic impact of the war, the role of women, cinema as a propaganda media, and the role of sports. By 1941, the Germans had accomplished an extraordinary military feat: operating with virtual impunity, their U-boats had converted the western Atlantic and Caribbean into cemeteries of Allied shipping, and this without a single base west of France's Bay of Biscay. The Allies had to commit 30 warships to each of German Admiral Dönitz's U-boats. During the most active phase, February 1942 to August 1943, Admiral Dönitz's "wolf packs" had sunk half of the 5,60o merchant ships existent in 1939. The Germans had given the lie to the supposed geopolitical hegemony proclaimed by the Monroe Doctrine. Eventually, the

2 The term was coined by the undisputed authority on this period, Fitzroy André Baptiste in War, Cooperation and Conflict: The European Possessions in the Caribbean 1939-1945 (New York: Greenwood Press, 1988).

3 Others in the broader project are Jorge Rodríguez Beruff, 2007, Strategy as Politics: Puerto Rico in the Eve of the Second World War (San Juan: Editorial de la Universidad de Puerto Rico); Jorge Rodríguez Beruff \& José L. Bolívar Fresneda, 2012, Puerto Rico en la Segunda Guerra Mundial: Baluarte del Caribe (San Juan: Ediciones Callejón). 
U.S. efforts to reclaim dominance of the sea and guarantee the defense of the Panama Canal was achieved through a string of bases running from Key West Florida through Cuba, Puerto Rico, the U.S. Virgin Islands, the Eastern Caribbean down to Trinidad, Northeast Brazil, and the Guianas. It took air, navy, and land forces to defeat the Nazi threat. Franklin Delano Roosevelt, for one, was keenly aware of the changed geostrategic environment: "The whole orientation of this country in relation to the continent ... has to be changed ... Any possible attack has been brought infinitely closer than it was five years or 20 years or 50 years ago" (p. 98).

Rodríguez Beruff describes one of the critical aspects of that changed geostrategic environment: the presence in 1940-42 of a large French fleet in Martinique under the command of Admiral Georges Robert, a pro-Vichy Fascist if not openly pro-Nazi. It was the most formidable naval fleet in the Eastern Caribbean at the time, to wit: aircraft carrier Beárn with 700 men and 106 of the most modern U.S.-built aircraft on board. Destined for the Battle of France the fleet now posed a real threat to the Panama Canal. The light cruiser Emile Bertín carried the 300 tons of gold (some US $\$ 300$ million) from the Bank of France. There were three modern cruisers (Esterel, Barfleur, and Quercy), the long-range submarine Surcouf, several smaller subs, and nine merchant marine ships. There was also in Martinique an army garrison of 1800 battle-ready men. Add to this potential menace the German U-boats that were already plying the Caribbean Sea and which, (unconfirmed) rumor had it, were provisioning off Guadeloupe. Such was the American apprehension over the plans of Admiral Robert that they made ready a so-called "Special Plan Three": the invasion of Martinique with an expeditionary force out of New York composed of 8,ooo men, one battle ship, one aircraft carrier, three cruisers, and a number of destroyers. The British also moved into position the two destroyers they had in the area. Rodríguez Beruff describes the delicate negotiations with Robert. He was invited and fêted in Puerto Rico and allowed to return to France, and this ended the confrontation. The ships were moth-balled and the crews (who so wished) returned to France.

One thing this volume makes clear is that despite the fact that these years witnessed significant constitutional watersheds, the human dimensions of the impact of the war have been largely forgotten in Puerto Rico and most of the Caribbean. ${ }^{4}$ As Silvia Alvarez Carbelo writes in a most interesting chapter on the Puerto Rican soldiers who served in World War II and Korea, Habian pagado

4 A rare exception is the splendid study by Trinidadian Gaylord T.M. Kelshall, 1988, The U-Boat War in the Caribbean (Port-of-Spain: Paria Publishing). 
el sacrificio de la ausencia, ahora pagarían el del olvido (p. 411-They paid the price by being absent; now they would pay the price of being forgotten.)

The essay by Luís Rafael Burset Flores, a bilingual Judge Advocate sent on duty to all the countries in Central America, tells us quite a bit about subjectivity. At a time when U.S. liberal officials and academics were describing the miserable living conditions of the Puerto Rican jibaro, Burset Flores makes odious comparisons with virtually every other country except Costa Rica. He has one description for them all: "Ni el pueblo más malo de Puerto Rico puede compararse" (p. 451). That might very well have been true in a comparative, relative deprivation sense, but the reality was that U.S. attention to Puerto Rican development really began with the war and accelerated after the war as Burset Flores himself notes in his substantive chapter (pp. 231-292).

This volume ends with an interesting and strongly independentista essay by Rafael Chabran, "El escribir la Guerra con sangre boricua: El tema de la guerra en la literatura de Puerto Rico." Thoroughly researched and elegantly presented, Chabran's chapter repeatedly speaks of the "militarization" of Puerto Rican society by the "ideological penetration" of the U.S. military. He researches Puerto Rican writing during the Spanish Civil War, World War II, Korea, and Vietnam to prove his point. To the extent that "militarism" is the pervasive emphasis on the military in the culture and the primacy of military solutions in political affairs, Chabran fails to demonstrate that this is a Puerto Rican cultural tradition. ${ }^{5} \mathrm{He}$ cannot find a single Puerto Rican literary piece on World War II: none on the Spanish Civil War, a few on the Korean War (where Puerto Ricans were among the most decorated troops), and only one "testimonial" on the Vietnam War (in which 48,ooo Puerto Ricans fought). Hardly the literary production of a militarist society. All in all, and despite the uneven quality of the contributions, this volume makes clear that Puerto Rican scholars have set an admirable example of how to fill that major gap in contemporary Caribbean history: the "Battle of the Caribbean."

One period that has most definitely not been forgotten is the one dominated by the scholarship, personality, and political life of Eric Williams of Trinidad and Tobago. The shelves sag from the weight of books on this extraordinary figure and this was true even before Selwyn Ryan's massive, and definitive, 842-page tome was added. ${ }^{6}$ This is why it is strange indeed to hear Maurice St. Pierre tell us that he hopes that his study will fill the "lacuna" of studies

5 See Alfred Vagts, 1981, A History of Militarism (New York: Greenwood Press Reprint).

6 Selwyn Ryan, 2009, Eric Williams: The Myth and the Man (Mona, Jamaica: University of the West Indies Press). 
on Eric Williams (p. 4). There certainly is no such lacuna, only varieties of interpretations and emphases. St. Pierre's work is proof of that. His contribution is to recall and revise those parts of the story that have been, if not ignored, at least left undeveloped, intentionally or unintentionally. And, let it be said, Eric Williams was himself guilty of much of this historical amnesia. Three cases deserve to be mentioned.

First, Williams's 1954 debate with the Benedictine Dom Basil Matthews which St. Pierre correctly notes was a major occasion in the intellectual life of the colony, and to which he deservedly dedicates eight pages. In the Rev. Matthews Williams faced a studious Trinidadian with a 1947 Ph.D. in sociology from Fordham University. Upon his return to Trinidad Matthews published his dissertation on the topic which had already drawn the attention of other scholars, the crisis in the West Indian family. ${ }^{7}$ Matthews showed that he was acquainted with some of those studying the topic. ${ }^{8}$ It can be said that this debate and the back-and-forth that followed in the press were the true beginnings of what Lloyd Best would later call "doctor politics" in the island.

Williams certainly had the best of it, at least in social-science terms, since Matthews's adamancy that only a Roman Catholic marriage could exempt couples from "living in sin" could sit well only with the most devout Catholics. Trinidadians and West Indians generally refer to such unions as simply "living together" or having a "keeper relationship." St. Pierre notes that the longer-term significance of the debate was that Williams developed a lasting reputation for being anti-Catholic and antagonistic to the small élite of that majority religion, the white French Creoles. On the positive side, it did establish Williams as a debater of note. He would later bring this style of educated speech to his public addresses in the so-called University of Woodford Square.

St. Pierre also does service to Trinidad historiography by revisiting the role, both intellectual and political, of Albert Gomes. Rather than the corrupt reactionary and "charlatan" Williams portrayed him to be, Gomes had been crucial in giving birth to literary commentary and critiques through his magazine The Beacon, established in 1931. By using his own modest capital, he introduced the likes of Alfred Mendes, C.L.R. James, and Ralph de Boissière to the soci-

7 Strangely, St. Pierre does not cite Dom Basil Matthews, 1953, Crisis in the West Indian Family (Port-of-Spain: Extramural of the University College of the West Indies).

8 E. Franklin Frazier, 1939, The Negro Family in the United States (Chicago: University of Chicago Press); Fernándo Henríques, 1953, Family and Colour in Jamaica (London: Eyre \& Spottiswoode) and 1959, "West Indian Family Organization," American Journal of Sociology 55: 30-37. Matthews also appeared to be acquainted with the work of Edith Clarke, later published as My Mother Who Fathered Me (London: George Allen and Unwin, 1957). 
ety. Gomes was also a pioneer trade union leader and politician in the difficult colonial years. St. Pierre makes good use of British and American consular dispatches which put Gomes in a good light as thinker and activist. Sad, indeed, that Gomes's autobiography, Through a Maze of Colour (Port-of-Spain: Key Caribbean, 1974) is one of the most overlooked books in the early history of Trinidadian national politics.

Finally, St. Pierre's description of Eric Williams-already at odds with his employer the Caribbean Commission, yet living in an up-scale neighborhood on Lady Chancellor Road with a big salary paid by the Commission, and driving the only Buick on the island - is relevant in terms of the "what if" of history. Contrary to the generally accepted interpretation of an inner-directed Williams on a linear path to power, St. Pierre submits his prepolitical career to a counterintuitive analysis. What would he have done if the Caribbean Commission had given him the promotion he wished for? What if his application for a teaching job at the University College of the West Indies had not been rejected? What if his suggestion in 1951 to Puerto Rican Governor Luís Muñoz Marín that he direct an "Institute of Colonial Affairs" with research emphasis on the Caribbean at the University of Puerto Rico had not been ignored? ${ }^{9}$ Since none of these ambitions materialized, Williams entered politics. On the advice of various friends he began this new phase by changing his "posh" house for one in lower-middle-class Woodbrook and his huge American Buick for a Britishmade "modest Vauxhall" (p. 9o).

St. Pierre is also good at demonstrating that Williams entered Trinidad politics through the big door, indebted to no particular sector or trade union, not even the Teachers' Economic and Cultural Association which had long agitated for his entry and to which, says St. Pierre, he gave "very short shrift" (p. 99). In terms of what St. Pierre calls the "anti-colonial tradition," Williams represented a "deviant" (as in different and exceptional) case in that he virtually forged his own tradition, and much of the society followed that tradition from 1956 until his death in 1981. This more than anything else is the message of St. Pierre's interesting book.

Varied as these three books are, they represent accurately this enormously complex region we describe with the generalization, "the Caribbean."

9 See Humberto García Muñiz, "Eric Williams and C.L.R. James: Intellectual Symbiosis and Political Counterpoint" (unpublished ms.), pp. 25-26. 